\title{
Erratum to: Involvement in bullying as predictor of suicidal ideation among 12- to 15-year-old Norwegian adolescents
}

\author{
Anne Mari Undheim • Anne Mari Sund
}

Published online: 31 January 2013

(C) Springer-Verlag Berlin Heidelberg 2013

Erratum to: Eur Child Adolesc Psychiatry

DOI 10.1007/s00787-012-0373-7

In the original publication, the name of the second author was inadvertently missed. The second author for this paper is Anne Mari Sund.

The online version of the original article can be found under doi:10.1007/s00787-012-0373-7.

\footnotetext{
A. M. Undheim ( $\square)$

Norwegian University of Science and Technology,

Trondheim, Norway

e-mail: anne.m.undheim@ntnu.no

A. M. Sund

Norwegian University of Science and Technology,

St Olav University Hospital, Trondheim, Norway
} 